\title{
Distribution of Haptoglobin Subtypes in Greeks
}

\author{
B. ANGELOPOULOS, A. TSOUKANTAS, and E. DANOPOULOS
}

From the Department of Pathological Physiology, Athens University

Human haptoglobin, the serum haemoglobinbinding protein, can be differentiated into three common phenotypes ( $\mathrm{Hp} \mathrm{I-I,} \mathrm{Hp} \mathrm{2-I,} \mathrm{and} \mathrm{Hp2-2)}$ by means of starch gel electrophoresis at $p \mathrm{H} 8.6$ (Smithies, 1955). These differences were thought to be determined by a pair of allelic genes $\mathrm{Hp}^{1}$ and $\mathrm{Hp}^{2}$ (Smithies and Walker, 1955, 1956). However, chemical reduction of purified haptoglobin followed by electrophoresis in starch gels, prepared in formic acid buffer containing $8 \mathrm{M}$ urea, enabled Connell, Dixon, and Smithies (1962) and Smithies, Connell, and Dixon (1962a) to classify individuals of phenotype $I-I$ into three subphenotypes, HpIF-IF, HpIF-IS, and HpISIS. These three subphenotypes are controlled by two alleles, $\mathrm{Hp}^{1 \mathrm{~F}}$ and $\mathrm{Hp}^{1 \mathrm{~s}}$. People of haptoglobin phenotype 2-I could also subtyped in a similar fashion into $\mathrm{Hp2-IF}$ or $\mathrm{Hp}_{2}-\mathrm{IS}$. Thus, a series of six phenotypes in the haptoglobin system can now be recognized (HpIF-IF, IF-IS, IS-IS, 2-IF, 2-IS, and 2-2).

Chemical reduction of purified haptoglobin separates the protein into two polypeptide chains. Only the $\alpha$ chain has been found to vary in the six phenotypes, and the allele designations are referred to the $\alpha$ chain. The $\beta$ chain appears to be unaffected by the genotype of the Hp locus (Smithies, Connell, and Dixon, 1962b). Chemical studies on the $\alpha$ chains (Smithies et al., I962b; Dixon, Smithies, and Connell, 1962) have disclosed a single amino acid difference between the $\alpha^{15}$ and the $\alpha^{1 F}$ chain. The $\alpha^{2}$ chain has characteristics of both $\alpha^{1 \mathrm{~S}}$ and $\alpha^{1 \mathrm{~F}}$ chains and appears to represent the unequal fusion of two $\alpha^{1}$ chains. However, two $\alpha^{2}$ chain variants were found in a population of Indians from Brazil (Nance and Smithies, 1963).

Although the distribution of the three common phenotypes in various populations is well known, very little information on the distribution of the subtypes of haptoglobin $\mathrm{I}-\mathrm{I}$ is available. Two

Received March 31, 1966. interesting surveys (Giblett and Brooks, 1963; Shim and Bearn, I964) of the distribution ofo haptoglobin subtypes in various populations have ${ }_{i}^{\omega}$ shown that oriental populations are restricted to the in $\mathrm{Hp}^{1 \mathrm{~s}}$ allele, whereas both $\mathrm{Hp}^{1 \mathrm{~s}}$ and $\mathrm{Hp}^{1 \mathrm{~F}}$ alleles $\sigma$ are present in Caucasian and Negro populations.음 In Caucasians, in particular, about $30 \%$ of the $\mathrm{Hp}^{1}$ gene frequency consists of $\mathrm{Hp}^{\mathbf{1 F}}$ alleles.

The purpose of this paper is to present data on the distribution of haptoglobin subtypes in Greek ${ }_{3}^{\mathbb{N}}$ population.

\section{Material and Methods}

The common haptoglobin types were determined in. 2026 healthy Greek adults. Sera were stored at? $-20^{\circ} \mathrm{C}$. Of 2026 ( 172 of phenotype $I-I$ and 430 of phenotype 2-I), 602 were examined for haptoglobin subtypes. Haptoglobin purification was performedo according to the method of Smithies et al. (I962a). 요 Vertical starch gel electrophoresis was carried out with the standard arrangement described by Smithies (I959), $\overrightarrow{\overrightarrow{0}}$ except that the electrodes were reversed and a formate 3 bridge solution ( $p \mathrm{H}_{3} .7$ ) was used in the two lower and front upper electrode chambers. A voltage gradiento of approximately 5 volts $/ \mathrm{cm}$. was applied for $18-20$ hours at $18^{\circ}-20^{\circ} \mathrm{C}$. Under these conditions, the resolution between the two types of $\alpha^{1}$ polypeptide chains was satisfactory (Fig.).

\section{Results and Discussion}

The number of samples examined, the distribu-O tion of phenotypes $\mathrm{I}-\mathrm{I}, 2-\mathrm{I}$, and $2-2$, as well as the frequencies of genes $\mathrm{Hp}^{1}$ and $\mathrm{Hp}^{2}$ in Greek population are summarized in Table I (Angelopoulos, Karalis, and Danopoulos, 1966).

The distribution of haptoglobin subtypes and theN gene frequencies of $\mathrm{Hp}^{1 \mathrm{~F}}$ and $\mathrm{Hp}^{1 \mathrm{~S}}$ are shown in Table II.

Smithies et al. (I962a) examined a random sample of 93 White American and Canadian blood donors and estimated the $\mathrm{Hp}^{1 \mathrm{~S}}$ and $\mathrm{Hp}^{1 \mathrm{~F}}$ frequency to be 0.24 and 0.16 , respectively. Giblett and Brooks (1963), by testing the sera of 66 Whiteo Americans, gave a frequency of 0.25 for $\mathrm{Hp}^{1 \mathrm{~s}}$ 


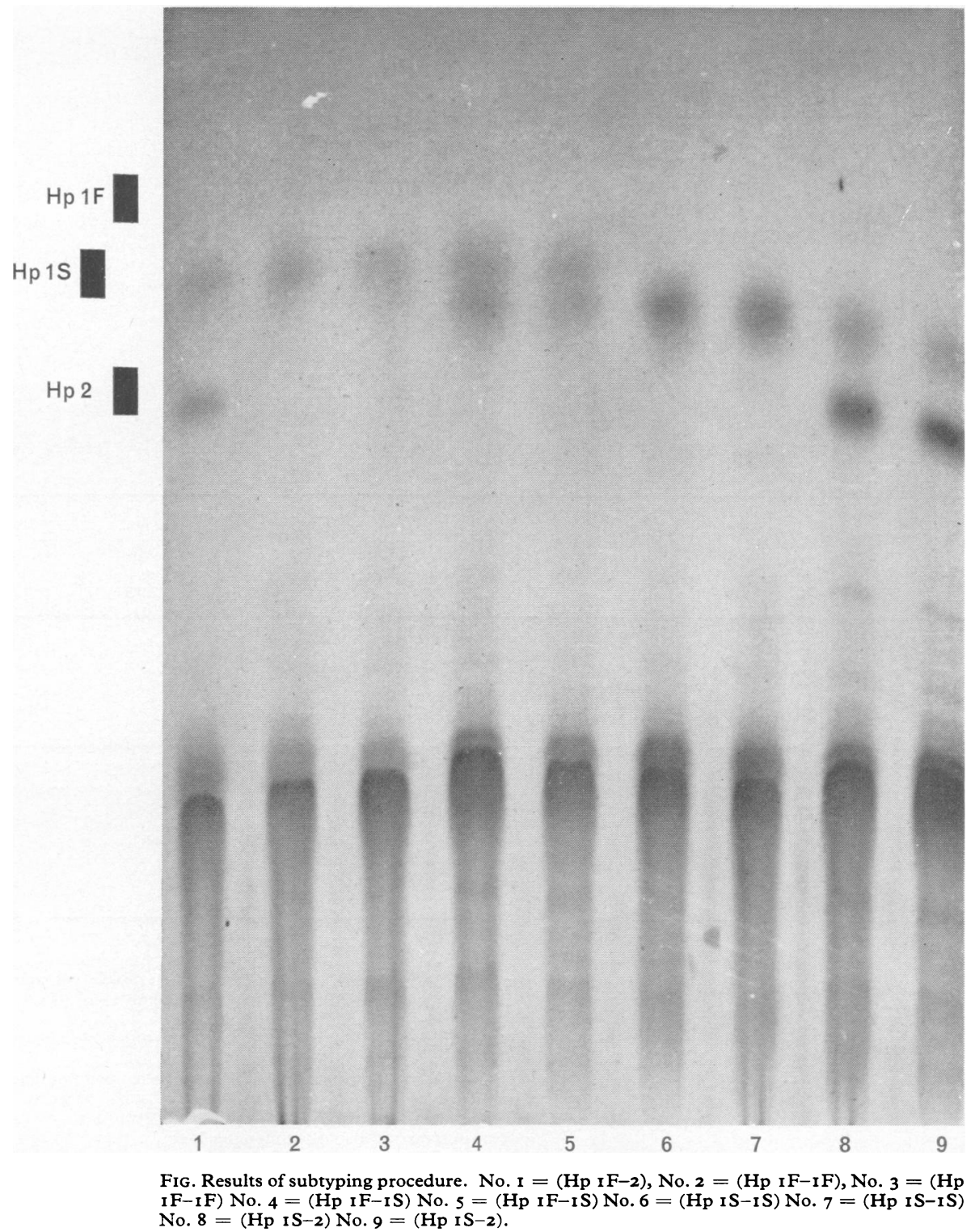

and 0.13 for $\mathrm{Hp}^{1 \mathrm{~F}}$. Shim and Bearn (1964) examined a sample of 72 Italians and estimated the $\mathrm{Hp}^{1 \mathrm{~S}}$ and $\mathrm{Hp}^{1 \mathrm{~F}}$ frequency to be 0.25 and $0.1 \mathrm{I}$, respectively. The observations by Giblett and Brooks (1963), that Oriental populations have the $\mathrm{Hp}^{1 \mathrm{~s}}$ allele whereas Caucasian and Negro populations have both $\mathrm{Hp}^{1 \mathrm{~S}}$ and $\mathrm{Hp}^{1 \mathrm{~F}}$ alleles, were confirmed by the study of Shim and Bearn
(1964) who extended their investigation to many Mongolian populations.

A comparison of the results obtained in the present study with those published by Giblett and Brooks (1963), Shim and Bearn (1964), and Smithies et al. (I262a) is illustrated in Table III.

Table III illustrates that the $\mathrm{Hp}^{1 \mathrm{~F}}$ gene frequency in the Greek population is a little higher 
TABLE I

DISTRIBUTION OF HAPTOGLOBIN PHENOTYPES AND FREQUENCIES OF GENES $\mathrm{Hp}^{1}$ AND $\mathrm{Hp}^{2}$ IN THE GREEK POPULATION

\begin{tabular}{|c|c|c|c|c|}
\hline \multirow{2}{*}{ Phenotypes } & \multirow{2}{*}{$\begin{array}{l}\text { Population } \\
\text { Proportion } \\
\text { (P) }\end{array}$} & \multirow{2}{*}{$\underset{\text { Proportion }}{\text { Sample }}$} & \multicolumn{2}{|c|}{ Gene Frequency } \\
\hline & & & $\mathrm{Hp}^{1}$ & $\mathrm{Hp}^{2}$ \\
\hline $\begin{array}{ll}\text { Hp } & \text { I-I } \\
\text { Hp } 2-I \\
\text { Hp } 2-2\end{array}$ & $\begin{array}{l}224 \\
928^{*} \\
874\end{array}$ & $\begin{array}{l}0.1096 \\
0.4586 \\
0.4318\end{array}$ & 0.339 & 0.661 \\
\hline Total & 2026 & $I \cdot 0000$ & & \\
\hline
\end{tabular}

* 9 were 2-I modified.

TABLE II

DISTRIBUTION OF HAPTOGLOBIN SUBTYPES AND FREQUENCIES OF GENES Hp ${ }^{1 F}$ AND Hp ${ }^{18}$ IN THE GREEK POPULATION

\begin{tabular}{|c|c|c|c|c|c|c|c|c|c|}
\hline \multirow{2}{*}{ Total No. Tested } & \multirow[t]{2}{*}{$\mathbf{I}-\mathbf{I}$} & \multirow[t]{2}{*}{$2-1$} & \multirow[t]{2}{*}{$\mathbf{I F}-\mathbf{I} \mathbf{F}$} & \multirow[t]{2}{*}{ IF-IS } & \multirow[t]{2}{*}{ IS-IS } & \multirow[t]{2}{*}{$2-I F$} & \multirow[t]{2}{*}{$2-I S$} & \multicolumn{2}{|c|}{ Gene Frequency } \\
\hline & & & & & & & & $\mathrm{Hp}^{1 \mathrm{~F}}$ & $\mathrm{Hp}^{1} \mathrm{~s}$ \\
\hline 602 & 172 & 430 & 30 & $8 I$ & 61 & 171 & 259 & 0.137 & 0.202 \\
\hline
\end{tabular}

TABLE III

HAPTOGLOBIN GENE FREQUENCIES IN CAUCASIANS

\begin{tabular}{|c|c|c|c|c|c|}
\hline \multirow{2}{*}{ Population } & \multirow{2}{*}{ No. Tested } & \multicolumn{3}{|c|}{ Gene Frequency } & \multirow{2}{*}{ Reference } \\
\hline & & $\mathrm{Hp}^{1 \mathrm{~F}}$ & $\mathrm{Hp}^{1 \mathrm{~s}}$ & $\mathrm{Hp}^{1 \mathrm{~F}}: \mathrm{Hp}^{1}$ & \\
\hline $\begin{array}{l}\text { American } \\
\text { American } \\
\text { Italian } \\
\text { Greek }\end{array}$ & $\begin{array}{r}66 \\
93 \\
72 \\
602\end{array}$ & $\begin{array}{l}0.133 \\
0.16 \\
0.118 \\
0.137\end{array}$ & $\begin{array}{l}0.251 \\
0.24 \\
0.252 \\
0.202\end{array}$ & $\begin{array}{l}0.346 \\
0.319 \\
0.403\end{array}$ & $\begin{array}{l}\text { Giblett and Brooks (1963) } \\
\text { Smithies et al. (1962a) } \\
\text { Shim and Bearn (1964) } \\
\text { Present study }\end{array}$ \\
\hline
\end{tabular}

than in the Italian and White American populations.

\section{Summary}

The haptoglobin subtypes after chemical purification of haptoglobin were studied in 602 healthy Greek adults.

The $\mathrm{Hp}^{1 \mathrm{~F}}$ and $\mathrm{Hp}^{1 \mathrm{~s}}$ gene frequencies were found to be 0.137 and 0.202 , respectively. Our results are compared with the results of other published investigations.

\section{REFERENCES}

Angelopoulos, B., Karalis, D., and Danopoulos, E. (1966). The distribution of serum haptoglobin types in Greek population and their correlation with blood groups. In the press.

Connell, G. E., Dixon, G. H., and Smithies, O. (r962). Subdivision of the three common haptoglobin types based on "hidden" differences. Nature (Lond.), 193, 505.
Dixon, G. H., Smithies, O., and Connell, G. E. (1962). Chemicak studies on genetic variants of human haptoglobin. Fed. Proc., 21 408.

Giblett, E. R., and Brooks, L. E. (1963). Haptoglobin sub-types in three racial groups. Nature (Lond.), 197,576 .

Nance, W. E., and Smithies, O. (1963). New haptoglobin alleles: a prediction confirmed. ibid., 198,869 .

Shim, B.-S., and Bearn, A. (I964). The distribution of haptoglobin subtypes in various populations, including subtype patterns in some nonhuman primates. Amer. F. hum. Genet., 16, 477.

Smithies, O. (1955). Zone electrophoresis in starch gels: group variations in the serum proteins of normal human adults. Biochem. F., 61, 629 .

- (1959). An improved procedure for starch-gel electrophoresis: further variations in the serum proteins of normal individuals. N ibid., 71,585 .

-, Connell, G. E., a.nd Dixon, G. H. (I962a). Inheritance of N haptoglobin subtypes. Amer. F. hum. Genet., 14, 14.

- , and - - (1962b). Chromosomal rearrangements and the evolution of haptoglobin genes. Nature (Lond.), 196, 232.

$\longrightarrow$, and Walker. N. F. (I955). Genetic control of some serum proteins in normal humans. ibid., 176, 1265.

- , and - (1956). Notation for serum-protein groups and the genes controlling their inheritance. ibid., 178, 694 . 